\title{
SZATMÁRI ADRIENN
}

\section{Vezetői kompetenciák a belügyi rendszerben}

2012 és 2014 között a Belügyi Tudományos Tanács Alkalmazott Pszichológiai Munkacsoportja kiemelt és komplex kutatást folytatott a belügyi vezetői kompetenciák kapcsán, ez megalapozta a jelenleg is müködő új és egységes belügyi vezetö-kiválasztási rendszert. A kutatás a belügyminiszter irányitása alá tartozó szervek hivatásos állományú tagjainak továbbképzési és vezetöképzési rendszeréröl, valamint a rendészeti utánpótlási és vezetői adatbankról szóló 2/2013. (I. 30.) BM rendelet (a továbbiakban: rendelet) megalkotásához szükséges alappontokat tárta fel, meghatározta azt a tizenhárom egységes belügyi vezetői kompetenciát, amelyet az ÁROP-2.2.17-2012-2013-0001 azonosítószámú Új közszolgálati életpálya címü kiemelt projekt keretén belül kialakított vezető-kiválasztási rendszer tudományosan alátámasztottan és egy összetett informatikai rendszer által támogatottan vizsgál a Belügyminisztérium Közszolgálati Személyzetfejlesztési Főigazgatóságán. A továbbiakban e kompetenciák rendszerét és struktúráját kívánom bemutatni.

\section{Vezetői kompetenciákról általában}

Általában véve a kompetenciák vizsgálatának kezdete az 1960-as évekre tehető, amikor is a korábbi kutatások az eredményes munkavégzést és beválást nem tudták megfelelőképpen elöre jelezni. Az Egyesült Államokban elsőként McClelland dolgozta ki a kompetenciaalapú kiválasztás módszertanát, míg hazánkban az egyik legnagyobb kompetenciaalapú kiválasztáskutatás a rendvédelem területén a nemzetközi szinten is támogatott Twinning-projekt volt Virág és munkatársai közremüködésével ${ }^{1}$.

A kompetencia fogalma a különböző szakterületek értelmezése alapján széles spektrumon mozog². A munka világában általában a gyakorlatban meg-

\footnotetext{
1 Hegedűs Judit: A vezető-kiválasztás elméleti háttere. In: Hegedűs Judit (szerk.): Tanulmánykötet a belügyi vezető-kiválasztási eljárásról. Belügyminisztérium, Budapest, 2014, 6. o.

2 Kovács Gábor: A rendészeti szervek szervezeti kultúrájának összetevői és sajátosságai, a téma feldolgozása a Rendőrtiszti Főiskola vezetéselméleti oktatásában. In: Gaál Gyula - Hautzinger Zoltán (szerk.): Tanulmányok „A rendészet kultúrája - kulturált rendészet” című tudományos konferenciáról. Pécs, 2009, 223-234. o. [Pécsi Határőr Tudományos Közlemények X.]
} 
kívánt viselkedéses repertoárt jelenti, amely beépíti az adott szervezeti egység értékeit és céljait. Brunner értelmezése szerint a kompetencia az intelligencia egy tágabb értelmezése, vagyis a „mit” tudásán túl a „hogyan”-t is magában foglaló operatív intelligencia. További szerzők szerint a kompetencia részben öröklött, részben tapasztalás-, tanulásalapú személyes jellemző, tudás, attitüd, amelynek segítségével a minket körülvevő helyzetekhez, változásokhoz eredményesen vagyunk képesek alkalmazkodni, és hatékonyan megoldani feladatokat, problémákat. Spencer ,jéghegymodell"-jében ${ }^{3}$ a kompetenciák ismeretekből, tudásból; jártasságokból, készségekből, képességekből; szociális szerepekből és értékekböl; énképböl; végül pedig személyiségvonásokból és motivációkból állnak. Leplat értelmezésében ${ }^{4}$ társadalmi folyamatokba ágyazottan elméleti és tapasztalati tanulás útján válunk hozzáértőkké, tehát a kompetencia kialakítható, megszerezhető, modellezhető és fejleszthető. A belügyi kompetenciakutatáskor a fogalom értelmezése során a kiváló és/vagy hatékony munkateljesítményre helyeződik a hangsúly, amely különböző akciók, az adott tevékenység céljához illeszkedő viselkedéses és magatartásmintákban, korábban megszerzett tárgyi és tapasztalati ismeretekben, személyes adottságok és motivációs állapotok megnyilvánulása során hangsúlyozódik. Általában a vezetői kompetenciák a következő csoportba sorolhatók ${ }^{5}$ :

- vezetés és döntés;

- támogatás és együttmüködés;

- kapcsolatteremtés és előadókészség;

- elemzés és értelmezés;

- kreativitás és fogalomalkotás;

- szervezés és megvalósítás;

- alkalmazkodás és kihívások kezelése;

- vállalkozó kedv és teljesítmény.

3 Szabó Szilvia: Vezetői kompetenciaalapú képzés a rendvédelem (rendőrség, határörség) állománya körében. Kard és Toll, 2006/3., 131-140. o.

4 Malét-Szabó Erika: A belügyi vezetö-kiválasztási rendszer tudományos megalapozása - avagy egy belügyi kutatás első eredményei. In: Gaál Gyula - Hautzinger Zoltán (szerk.): Tanulmányok „A változó rendészet aktuális kihívásai" címü tudományos konferenciáról. Pécs, 2013, 141-148. o. [Pécsi Határör Tudományos Közlemények XIV.]

5 Hegedűs Judit: i. m. 7. o. 


\section{A vezetői kompetenciák jellegzetességei a háttértényezők függvényében}

A vezetői kompetenciák háttértényezői között kiemelkedő helyen a nemi faktor kérdésköre szerepel, amely jelentősebb, mint a szintén hangsúlyosnak tartott bőrszín vagy életkor. A nők egyre nagyobb arányban jelennek meg nemcsak a globális munkaerőpiacon, hanem az alapvetően maszkulinnak tartott rendszereken belül is, ezzel - jelen összefoglalásban külön nem részletezve - a genderkutatások hangsúlyozottan foglalkoznak. A nők aránya a rendvédelmi szerveken belül egyértelmúen alulreprezentált, nem éri el az európai negyvenszázalékos arányt. Bár az elmúlt évtizedekben egyértelmü növekedés tapasztalható, napjainkban ez az arány a húsz százalékhoz közelít. Az elmúlt évszázadban jelentősen megváltozott a környezet, amelyben élünk, ennek következménye, hogy alapvetően megváltoztak azok a nemi szerepek, amelyek a korábbi évszázadokban szinte változatlannak tüntek ${ }^{6}$. A nők és férfiak biológiai és társadalmi okokból eltérő kompetenciái, az ebből következő hatékonysági követelmények miatt természetes a foglalkoztatásban a nemek szerinti elkülönülés. Nem a szegregáció okozza a társadalmi egyenlötlenségeket, hanem azok a munkaerőpiaci mechanizmusok, amelyek társadalmi hátránnyá formálják a foglalkozási struktúrában való elhelyezkedést ${ }^{7}$.

Sümegi ${ }^{8}$ összefoglalása szerint a nők munkaerőpiaci elhelyezkedése egy szervezeten belül egy piramissal szemléltethető. Általában a nők a foglalkoztatási piramis alsóbb szintjein helyezkednek el, ahol kevesebb a jövedelem és a presztízs, felfelé haladva pedig egyre kisebb számban jelennek meg. A sztereotip gondolkodás szerint a férfiakat a magasabb presztízst jelentő vagy a hatalommal, kapcsolati tőkével járó foglalkozások illetik meg. A vezetői beosztások felé haladva a nők egyre jobban lemaradnak az azonos képességü férfiak mögött, a vezetői beosztások betöltése iránti motivációjuk is csökken, és láthatóvá válik az „üvegplafon” jelenség, amely arra utal, hogy a nők felső pozícióba emelkedése láthatatlan akadályba ütközik ${ }^{9}$. Ez a jelenség bizonyítja a vertikális szegregáció fogalmát a rendvédelmi szerveken belül is, hiszen a felső vezetésben regnáló női vezetők aránya még igen csekély, a

6 Kopp Mária: Miért váltak a gender-kutatások központi jelentőségűvé a mai társadalomban? 2011. http://www.tavlatok.hu/net/cikk29kopp_k.htm.

7 Koncz Katalin: A munkaerőpiac nemek szerinti szegregációjának jellemzői, mechanizmusa és következményei. Közgazdasági Szemle, 2011/1., 74-94. o.

8 Sümegi Bernadett: Nők a vezetésben: nehézségek és lehetőségek. 2007. http//www.elib.kkf.hu

9 Luu Lan Anh Nguyen: A férfiak és nők a munka világában. Nemi szerepek a munkahelyen. Magyar Pszichológiai Szemle, 2005/1., 111-134. o. 
létszámuk inkább a középvezetésben jelentős. Az 1990-es népszámlálás adatai szerint a női vezetök és irányítók többsége 30 és 55 év közötti, a férfiak ennél némileg fiatalabbak. A férfiak korábban kerülnek vezetői és irányítói pozícióba, és - részben a magasabb nyugdíjkorhatár miatt - tovább vannak felelős beosztásban. Az adatok azt jelzik, hogy a nők számára jelentős gondot okoz a karrier, a magánélet és a családalapítás összehangolása. A kevesebb konfliktussal járó megoldás sokszor az, ha a szakmai előrehaladás átmenetileg háttérbe szorul, ez hozzájárul ahhoz, hogy a nők a szervezeti hierarchiának többnyire csak az alacsonyabb fokaira jutnak el ${ }^{10}$.

A XXI. században egyértelmúen tapasztalható a vezetési stílusok változása ${ }^{11}$. A korábban követendő férfi vezetöi stílus mellett a női erények is elötérbe kerültek, habár a női vezetés kapcsán még mindig tapasztalható egyfajta negatív attitüd. A vezetői kompetenciák nemi szempontú strukturálásakor kiemelendők Schein kutatásai ${ }^{12}$, aki a vezetői sztereotípiákkal kapcsolatos első vizsgálatait az Amerikai Egyesült Államokban kezdte az 1970-es években. E kutatások során nemcsak az ideális vezető jellegzetességeit keresték, hanem azt is szerették volna megtudni, hogy ezek a tulajdonságok menynyire illeszkednek a férfi, illetve a női nemhez. Vizsgálataik azt a feltevést igazolták, hogy a megkérdezett középszintü vezetők, akik akkor még többnyire férfiak voltak, rendre a férfiasnak vélt tulajdonságokkal jellemezték a sikeres, ideális vezetőt. Az ideális vezető sztereotípiája tehát lényegesen közelebb állt a férfiaknak, mint a nőknek tulajdonított jellegzetességekhez. Ezzel szemben a nők esetében eltünőben volt a sztereotip gondolkodás, ők már nem úgy tekintettek a sikeres menedzserekhez kapcsolható tulajdonságokra, mint amelyeket csak a férfiak tudnak felmutatni.

A további kutatások megállapították, hogy a nők vezetési stílusára rendszerint nem az egyszemélyes irányítás jellemző, inkább kollaboratív munkaformában szeretnek dolgozni, hatékonyabbak ott, ahol fontos szerep jut mások meghallgatásának, összességében a kommunikációnak. Képesek a beosztottaikra támaszkodni, és a konfliktusokat diplomatikusan igyekeznek megoldani. Sikerükhöz hozzájárul az empatikus kapcsolatkialakításra törekvésük is, illetve az a megállapítás, hogy a mai modern társadalomban a nőkre jellemző transzformációs vezetési stílus jobb eredményhez vezet, mint a

\footnotetext{
10 Nagy Beáta: Nők a vezetésben: nehézségek és lehetőségek. Szociológiai Szemle, 1993/3-4., 147-166. o. 11 Kovács Gábor: Az alap- és felsőfokú határőr tisztképzés sajátosságai a Zrínyi Miklós Nemzetvédelmi Egyetem Határőr Tanszékén 2002 és 2008 között. In: Gaál Gyula - Hautzinger Zoltán (szerk.): A modernkori magyar határrendészet száztíz éve. Budapest, 2013, 257-273. o.

12 Nagy Beáta - Vicsek Lilla Mária: Mit ér a női vezető szava? Századvég, 2006/41., 123-160. o.
} 
férfiaké13. A transzformációs vezetési stílusú személy kompetenciái között szerepel az elgondolkodtatás képessége, a hatékony motiválóképesség, az intellektuális ösztönzés és az egyénileg mérlegelés ${ }^{14}$. Általában elmondható, hogy a nők aprólékosan, precízen tudnak dolgozni, és képesek a figyelmüket megosztani, jobbak a csapatépítésben és a kommunikációban is, konszenzusra törekszenek, nyitottabbak, támogatóbbak, és jobban odafigyelnek másokra. A menedzsmentszempontú kultúra egyre jobban elismeri, hogy a női vezetők eszközei és készségei pozitív hatással vannak a munkacsoportokra, a munkafolyamatokra és a vállalatok sikerére. Nehézséget okoz azonban, hogy a nők emocionalitása befolyással lehet a döntéshozatalra, nehezebben hoznak meg súlyos és kemény döntéseket, és könnyebben manipulálhatók ${ }^{15}$.

Ezzel szemben a férfiak vezetési stílusa általában a versengéshez kötődik. Versenyorientáltabbak, hierarchikusak, célorientáltak, és katonásan viselkednek, az ö szemükben az ideális vezető kemény és független. Egy férfi vezetö utasítást ad, feladatot határoz meg. Noha a vezetői munka természetéhez nem kapcsolódik szorosan a fizikai erő és a technológiai ismeret, mégis a maszkulinitás mítosza továbbra is dominál a középosztálybeli diplomások körében. Ez kibontva azt jelenti, hogy továbbra is fontos szerepet játszik a (fizikai) tettrekészség, annak ellenére, hogy a vezetői munkában kizárólag a szellemi képességeknek lenne létjogosultságuk. Természetesen ezek az aspektusok visszavezethetők a szocializációs folyamatokra, hiszen a lányok esetében az empátia, az odafigyelés, az altruizmus, az önfeláldozás és az alkalmazkodóképesség állandóan és hangsúlyozottan jelen van az elsajátítandó szerepek között, míg a fiúknál sokkal fontosabb például az önérvényesítés, az agresszivitás, a karriervágy, illetve a versenyszellem.

Általánosságban elmondható tehát, hogy vannak alapkompetenciák, amelyek szükségesek ahhoz, hogy valakiből jó vezető válhasson, ezek pedig megtalálhatók mindkét nemnél. Természetesen nem mindenki bír a megfelelő kompetenciákkal, vezetői skillekkel, hiszen a két nem kompetenciakészlete eltérö, továbbá a készségek összekapcsolásában és jellegében is különböznek egymástól. A férfiak nem feltétlenül jobb vezetők, mint a nők, és fordítva. Számos kutatás bizonyítja, hogy az a szervezet tud igazán sikeres lenni, amelyik képes mindkét nem kompetenciáit, erősségeit megfelelően, szituatíve kiaknázni ${ }^{16}$.

\footnotetext{
13 Sümegi Bernadett: i. m.

14 John Antonakis - Bruce J. Avolio - Sivasubramaniam Nagaraj: Context and Leadership: An examination of the nine facor full-range leadership theory using the Multifactor Leadership Questionnaire. The Leadership Quarterly, vol. 14, 2003, pp. 261-295.

15 Sümegi Bernadett: i. m.

16 Nagy Beáta - Vicsek Lilla Mária: i. m.
} 


\section{Az egységes belügyi vezetői kompetenciák}

A belügyi kompetenciákat vizsgáló kutatás első szakaszában a különböző belügyi szervek specifikumait figyelembe véve kérdöíves felméréssel és interjútechnikai módszerekkel határozták meg azokat az adatokat, amelyeket rendészeti vezetőkből és pszichológusokból álló fókuszcsoportok tovább elemeztek és összegeztek. Az így kapott tizenöt elemü vezetői kompetenciarendszer strukturálása során végül tizenhárom kulcskompetencia meghatározására került sor.

A kompetenciák rendszerét két szinten alakították ki, egy közép- (osztályvezető és főosztályvezető-helyettes), illetve egy felső vezetői szinten (föosztályvezető, illetve magasabb beosztási szint) történt a fogalom meghatározásának elkülönítése. Az összvezetői kompetenciák alapvetően három fő kategóriára bonthatók ${ }^{17}$ :

- egyéni kompetenciák: megbízhatóság, terhelhetőség, kreativitás, rugalmasság, egyéni példamutatás, szakmai ismeret, stratégiai gondolkodás, cél- és feladatorientáltság, hatékony döntés, felelősségvállalás;

- szociális kompetenciák: kommunikációs készség, konfliktuskezelés, érdekérvényesítés, asszertivitás;

- vezetői kompetenciák: vezetői gondoskodás, vezetői funkciók ellátása, hatékony erőforrás-gazdálkodás.

A kompetenciák kialakításakor nehézséget okozott az egyes fogalmak közötti átfedés, így alakult ki a végső, 13 kulcskompetencia (táblázat). További nehézség volt, hogy egyes kompetenciák a kiválasztási eljárások során csupán longitudinálisan értelmezhetők, az egyes vizsgálati eljárásokban nem figyelhetők meg teljeskörüen. Harmadrészt, a meghatározott kompetenciák sok esetben nem pszichológiai-szakmai megfogalmazások, hanem általánosabb, hétköznapibb terminusok, amelyek azonban így jobban illeszkednek az aktuális belügyi kultúrához, elöírásokhoz, szokásrendszerhez.

A kompetenciák áttekintésekor látható, hogy a középvezetői és felső vezetői szinten mutatkozó vezetőikompetencia-különbségek elsősorban a szervezeti feladatok fókusza tekintetében tapasztalhatók. Középvezetői szinten elsősorban a saját, kisebb szervezeti egység mindennapi működtetésére he-

17 Malét-Szabó Erika: Az új belügyi vezető-kiválasztási rendszer elemeinek értékelése a szilárd erkölcsiség mutató mérésére javasolt SZEMmodell tükrében. In: Malét-Szabó Erika (szerk): Az erkölcsi értékrend és a személyiség közötti kapcsolat vizsgálati szempontjai. Belügyminisztérium, Budapest, 2015, 156-191. o. 
Az egységes belügyi vezetôi kompetenciák definíciója ${ }^{18}$

\begin{tabular}{|c|c|c|}
\hline KOMPETENCIÁK & KÖZÉPVEZETÖI SZINT & FELSÖ VEZETÖI SZINT \\
\hline $\begin{array}{c}1 . \\
\text { Következetesség, } \\
\text { kiszámíthatóság }\end{array}$ & $\begin{array}{l}\text { - A feladatot határidőre, a szakma sza- } \\
\text { bályainak megfelelően elvégzi. } \\
\text { - A vonatkozó normák betartása mellett } \\
\text { döntéseiben, tevékenységeiben követ- } \\
\text { kezetes. } \\
\text { - Feladatmeghatározásai, elvárásai, át- } \\
\text { láthatók, egyértelmüek. } \\
\text { - Viselkedése kiszámítató. }\end{array}$ & $\begin{array}{l}\text { - A feladatot határidőre, a szervezeti ér- } \\
\text { tékeknek megfelelően elvégezteti, } \\
\text { visszaellenőrzi és ellenőrizteti. } \\
\text { - Feladatmeghatározásai, elvárásai vilá- } \\
\text { gosak, egyértelmủek, lényegre törőek } \\
\text { és a szervezet céljaival összhangban } \\
\text { állnak. }\end{array}$ \\
\hline $\begin{array}{c}2 . \\
\text { Szakmai ismeret }\end{array}$ & $\begin{array}{l}\text { - Elméleti ismereteit, a feladat delegá- } \\
\text { lásában, végrehajtásában megszerzett } \\
\text { szakmai tapasztalatát a gyakorlatban } \\
\text { hatékonyan alkalmazza. } \\
\text { - A munka- és szervezeti folyamatokat } \\
\text { átlátja, azokban magabiztosan eliga- } \\
\text { zodik. }\end{array}$ & $\begin{array}{l}\text { - A feladat-végrehajtatásban megszer- } \\
\text { zett szakmai tapasztalatát a gyakorlat- } \\
\text { ban hatékonyan alkalmazza. } \\
\text { - A saját és az együttműködő szerveze- } \\
\text { tek rendszerét stratégiai szinten átlát- } \\
\text { ja, abban magabiztosan eligazodik. }\end{array}$ \\
\hline $\begin{array}{c}3 . \\
\text { Vezetői funkciók } \\
\text { ellátása }\end{array}$ & $\begin{array}{l}\text { - Tervezi, szervezi, irányítja, koordinál- } \\
\text { ja, ellenőrzi a szervezeti egysége te- } \\
\text { vékenységét. } \\
\text { - Az adott feladat eredményes ellátásá- } \\
\text { hoz szükséges erőforrásokat meghatá- } \\
\text { rozza, és ezek hatékony felhasználását } \\
\text { irányítja. }\end{array}$ & $\begin{array}{l}\text { - A szervezet eredményes müködéséhez } \\
\text { szükséges eröforrásokat megteremti, } \\
\text { és ellenörzi ezek hatékony felhaszná- } \\
\text { lását. }\end{array}$ \\
\hline $\begin{array}{c}4 . \\
\text { Reális önismeret, } \\
\text { önfejlesztési igény }\end{array}$ & $\begin{array}{l}\text { - Felismeri saját határait és fejlesztendö } \\
\text { területeit. Önismereti és önfejlesztési } \\
\text { igény jellemzi. } \\
\text { - A konstruktív kritikát elfogadja. }\end{array}$ & \\
\hline $\begin{array}{c}5 . \\
\text { Személyes } \\
\text { példamutatás }\end{array}$ & $\begin{array}{l}\text { - Szakmai tevékenységében, általános } \\
\text { emberi értékek területén, valamint a } \\
\text { szervezet iránti lojalitásában példát } \\
\text { mutat. }\end{array}$ & $\begin{array}{l}\text { - Szakmai tevékenysége és előélete pél- } \\
\text { daértékü. Megtestesíti az általános } \\
\text { emberi értékeket. } \\
\text { - A szervezetet hitelesen és méltón } \\
\text { megjeleníti és képviseli. }\end{array}$ \\
\hline $\begin{array}{c}6 . \\
\text { Rugalmas } \\
\text { alkalmazkodó- } \\
\text { képesség }\end{array}$ & $\begin{array}{l}\text { - Képes a munkavégzés során felvetődö } \\
\text { külső és belső problémák egyidejủ } \\
\text { kezelésére. } \\
\text { - A változó helyzeteket felismeri, és } \\
\text { azokhoz rugalmasan alkalmazkodik. } \\
\text {-A stresszt hatékonyan kezeli. }\end{array}$ & $\begin{array}{l}\text { - A külső, a szervezeti müködés irányá- } \\
\text { ba ható negatív nyomást csökkenti, és } \\
\text { pozitív átkeretezésre képes. } \\
\text { - Inspirálja és támogatja a változásokat. }\end{array}$ \\
\hline
\end{tabular}

18 Uo. 


\begin{tabular}{|c|c|c|}
\hline $\begin{array}{l}7 . \\
\text { Döntési képesség, } \\
\text { felelősségvállalás }\end{array}$ & $\begin{array}{l}\text { - A célok elérését segítő hatékony in- } \\
\text { tézkedések érdekében, idejében, hatá- } \\
\text { rozott, egyértelmüen megfogalmazott } \\
\text { döntést hoz. } \\
\text { - A sikeres feladat végrehajtása érdeké- } \\
\text { ben szükség esetén döntését korrigál- } \\
\text { ja, megváltoztatja, } \\
\text { - ezért felelösséget vállal. }\end{array}$ & $\begin{array}{l}\text { - A stratégiai célok elérését segítő dön- } \\
\text { téseket hoz; } \\
\text { - illetve az alárendeltségébe tartozók } \\
\text { döntéseit szükség esetén megváltoz- } \\
\text { tatja, és ezért felelősséget vállal. }\end{array}$ \\
\hline $\begin{array}{c}8 . \\
\text { Munkatársak } \\
\text { motiválása, } \\
\text { fejlesztése }\end{array}$ & $\begin{array}{l}\text { - Munkatársait ismeri, tisztában van a } \\
\text { képességeikkel, erősségeikkel, fej- } \\
\text { lesztendő területeikkel. } \\
\text { - Mindezt a munkakörülményekkel } \\
\text { együtt figyelembe véve képes a be- } \\
\text { osztottait motiválni és fejleszteni. } \\
\text { - Beosztottaival empatikus és toleráns. } \\
\text { - Képes csapatot építeni. }\end{array}$ & $\begin{array}{l}\text { - Az általa irányított és az alárendeltsé- } \\
\text { gébe tartozó szervezeti egységet, va- } \\
\text { lamint a közvetlen munkatársait isme- } \\
\text { ri, azok célorientált fejlesztésére } \\
\text { törekszik. }\end{array}$ \\
\hline $\begin{array}{c}9 . \\
\text { Konfliktuskezelés, } \\
\text { érdekérvényesítés }\end{array}$ & $\begin{array}{l}\text { - A konfliktushelyzeteket felismeri az } \\
\text { azokból adódó feszültségeket kezeli, } \\
\text { hatékony megoldásukra törekszik. } \\
\text { - A szervezeti egysége érdekeit hatéko- } \\
\text { nyan, a másik fél érdekeit is figye- } \\
\text { lembe véve képviseli és érvényesíti. } \\
\text { - Munkája során együttműködésre, } \\
\text { partnerségre törekszik. }\end{array}$ & $\begin{array}{l}\text { - A szervezetet érintő belső és külső } \\
\text { (társszervek, civil intézmények stb. } \\
\text { irányába) konfliktushelyzeteket felis- } \\
\text { meri, az azokból adódó feszültségeket } \\
\text { kezeli, hatékony megoldásukat mene- } \\
\text { dzseli. } \\
\text { - Az általa irányított szervezet vagy } \\
\text { szervezeti egység érdekeit befelé is } \\
\text { kifelé hatékonyan, a másik fél érdeke- } \\
\text { it is figyelembe véve képviseli és ér- } \\
\text { vényesíti. }\end{array}$ \\
\hline $\begin{array}{c}10 . \\
\text { Cél- és } \\
\text { feladatorientáltság }\end{array}$ & $\begin{array}{l}\text { - A célokat meghatározza és elfogadtat- } \\
\text { ja, azok között fontossági sorrendet } \\
\text { állít fel. } \\
\text { - A célokhoz kapcsolódó feladatokat } \\
\text { személyhez és határidöhöz kötötten } \\
\text { delegálja, és visszaellenörzi. }\end{array}$ & $\begin{array}{l}\text { - Az egész szervezetet érintő stratégiai } \\
\text { célokhoz kötődő feladatokat delegál } \\
\text { és ellenőriztet. }\end{array}$ \\
\hline $\begin{array}{c}11 . \\
\text { Kommunikációs } \\
\text { készség }\end{array}$ & $\begin{array}{l}\text { - Kommunikációja nyílt, öszinte, hite- } \\
\text { les, kétirányú. } \\
\text { - Szóban és írásban világosan, egyértel- } \\
\text { müen, érthetöen fogalmaz. } \\
\text { - Képes a különböző helyzetekben } \\
\text { adekvátan kommunikálni. }\end{array}$ & $\begin{array}{l}\text { - Strukturált, a szervezeti érdekeknek } \\
\text { megfelelően felépített, lényegre törő, } \\
\text { a másik fél érdekeit is figyelembe ve- } \\
\text { vő kommunikációt folytat minden } \\
\text { szinten, a szervezeten kívül és a szer- } \\
\text { vezeten belül is. Az egész szervezetet } \\
\text { érintő stratégiai célokhoz kötődő fel- } \\
\text { adatokat delegál és ellenőriztet. }\end{array}$ \\
\hline
\end{tabular}




\begin{tabular}{|c|c|c|}
\hline $\begin{array}{c}12 . \\
\text { Kreativitás, } \\
\text { innováció }\end{array}$ & $\begin{array}{l}\text { - Kezdeményező, nyitott az újszerú } \\
\text { megoldásokra, módszerekre, azokat } \\
\text { gyakorlatban alkalmazza. } \\
\text { - Felismeri, támogatja és ösztönzi az új } \\
\text { kezdeményezéseket. }\end{array}$ & $\begin{array}{l}\text { - Ösztönzi és támogatja az innovatív } \\
\text { kezdeményezéseket és visszajelzése- } \\
\text { ket. } \\
\text { - Részt vesz a szervezeti kultúra folya- } \\
\text { matos megújításában. }\end{array}$ \\
\hline $\begin{array}{c}13 . \\
\text { Rendszerszemlélet, } \\
\text { lényeglátás }\end{array}$ & $\begin{array}{l}\text { - Rendszerben és folyamatokban gon- } \\
\text { dolkodik, összefüggések felismerésére } \\
\text { képes. } \\
\text { - Elemzö-értékelö szemléletmód (tevé- } \\
\text { kenység) jellemzi. }\end{array}$ & $\begin{array}{l}\text { - Stratégiában, rendszerekben egymás- } \\
\text { hoz kapcsolódó alrendszerekben és } \\
\text { folyamatokban gondolkodik. } \\
\text { - Szélesebb körü, távlati összefüggések } \\
\text { felismerésére képes. }\end{array}$ \\
\hline
\end{tabular}

lyeződik a hangsúly, míg felső vezetői szinten a globális szervezet irányítása, innovatív, menedzser szempontú koordinálás és a külső kapcsolatteremtés hatékony müködtetése jelenik meg.

A kulcskompetenciák a gyakorlati érthetőség és használhatóság kedvéért a következő alkompetenciákra bonthatók ${ }^{19}$ :

1. Következetesség, kiszámíthatóság

- szabálytudat, fegyelmezettség,

- elvárások támasztása, következetesség;

2. Szakmai ismeretek

- szakmai elméleti ismeretek,

- szakmai összefüggések, folyamatok ismerete,

- testületismeret (hely- és személyismeret),

- szakmai tapasztalatok;

3. Vezetői funkciók ellátása

- tervezés, szervezés,

- irányítás, koordinálás, ellenőrzés;

4. Reális önismeret, önfejlesztési igény

- reális önismeret,

- önfejlesztési igény;

5. Személyes példamutatás

- hitelesség,

- szervezet iránti elkötelezettség,

- minőségre törekvés, igényesség;

6. Rugalmas alkalmazkodóképesség

- változó helyzethez való alkalmazkodás;

- pszichés terhelhetőség, hatékony stresszkezelés;

19 Uo. 
7. Döntési képesség, felelősségvállalás

- döntés-előkészítés,

- döntéshozás;

8. Munkatársak motiválása, fejlesztése

- személyre szabott motiválás, fejlesztés,

- személyészlelés, empátia, tolerancia,

- hatékony együttmüködés megteremtése;

9. Konfliktuskezelés, érdekérvényesítés

- tudatos, adekvát konfliktuskezelés,

- érdekképviselet és -érvényesítés,

- felelősségvállalás;

10. Cél- és feladatorientáltság

- célok meghatározása,

- feladatok személyhez kötése;

11. Kommunikációs készség

- Verbális kommunikáció,

- Nonverbális kommunikáció;

12. Kreativitás, innováció

- nyitottság, ösztönzés;

13. Rendszerszemlélet, lényeglátás

- elemző gondolkodás, lényeglátás,

- rendszergondolkodás,

- stratégiai gondolkodás.

\section{Zárógondolatok}

A Belügyi Tudományos Tanács Alkalmazott Pszichológiai Munkacsoportja által kezdeményezett belügyi vezetői kompetenciákhoz kapcsolódó kutatás a jelenlegi vezető-kiválasztási eljárás alapja. A kutatás 13 belügyi kulcskompetenciát határozott meg, majd az Új közszolgálati életpálya címủ ÁROP-projekt keretén belül hitelesítette, legalizálta és a vezető-kiválasztási eljárásba beépítette az új vezetőikompetencia-struktúrát, ezáltal a különböző belügyi szervek hivatásos állományú vezetői, illetve vezetőjelöltjei tudományosan jól körülírt ismérvek alapján vizsgálhatók, mérhetők és fejleszthetők. Természetesen a szervezetspecifikus különbségek továbbra is megtalálhatók, ezek megfelelő értelmezése azonban a vezető-kiválasztási eljárásban részt vevő értékelő személyek külön feladata. A belügyi vezetői kompetenciák mögött 
meghúzódó részletes és példaértékü, a szervek összefogásán alapuló munka olyan tudásalapú megközelítés, amellyel a vezetőkiválasztás intézménye nemzetközi szinten is elsőrangúvá vált. Ahhoz, hogy a továbbiakban is kiemelkedő, hiteles, megbízható és minőségi módon lehessen a belügyi szervek vezetöit kiválasztani ${ }^{20}$, illetve képezni, a kiválasztási rendszer folyamatos monitorozására és az aktuális eredményekből levont következtetések rendszerhez igazítására van szükség.

\section{IRODALOM}

Antonakis, John - Avolio, Bruce J. - Nagaraj, Sivasubramaniam: Context and Leadership: An examination of the nine facor full-range leadership theory using the Multifactor Leadership Questionnaire. The Leadership Quarterly, vol. 14, 2003

Hegedűs Judit: A vezető-kiválasztás elméleti háttere. In: Hegedűs Judit (szerk.): Tanulmánykötet a belügyi vezető-kiválasztási eljárásról. Belügyminisztérium, Budapest, 2014, 5-9. o.

Klein Sándor: Munkapszichológia. Edge 2000 Kiadó, Budapest, 2004

Koncz Katalin: A munkaerőpiac nemek szerinti szegregációjának jellemzői, mechanizmusa és következményei. Közgazdasági Szemle, 2011/1.

Kopp Mária: Miért váltak a gender-kutatások központi jelentőségüvé a mai társadalomban? 2011. http://www.tavlatok.hu/net/cikk29kopp_k.htm.

Kovács Gábor: A rendészeti szervek szervezeti kultúrájának összetevői és sajátosságai, a téma feldolgozása a Rendőrtiszti Főiskola vezetéselméleti oktatásában. In: Gaál Gyula Hautzinger Zoltán (szerk.): Tanulmányok „A rendészet kultúrája - kulturált rendészet” című tudományos konferenciáról. Pécs, 2009, 223-234. o. [Pécsi Határőr Tudományos Közlemények X.]

Kovács Gábor: A Nemzeti Közszolgálati Egyetem, mint a közszolgálati képzés bázisa: a jelenlegi helyzetkép, jövőbeni változások, fejlődési tendenciák és kihívások. In: Gaál Gyula Hautzinger Zoltán (szerk.): Tanulmányok „A biztonság rendészettudományi dimenziói változások és hatások” címủ tudományos konferenciáról. Pécs, 2012, 371-379. o. [Pécsi Határőr Tudományos Közlemények XIII.]

Kovács Gábor: Az alap- és felsőfokú határőr tisztképzés sajátosságai a Zrínyi Miklós Nemzetvédelmi Egyetem Határőr Tanszékén 2002 és 2008 között. In: Gaál Gyula - Hautzinger Zoltán (szerk.): A modernkori magyar határrendészet száztíz éve. Budapest, 2013, 257-273. o.

Malét-Szabó Erika: A belügyi vezető-kiválasztási rendszer tudományos megalapozása avagy egy belügyi kutatás első eredményei. In: Gaál Gyula - Hautzinger Zoltán (szerk.): Tanulmányok „A változó rendészet aktuális kihívásai” címủ tudományos konferenciáról. Pécs, 2013, 141-148. o. [Pécsi Határőr Tudományos Közlemények XIV.]

20 Kovács Gábor: A Nemzeti Közszolgálati Egyetem, mint a közszolgálati képzés bázisa: a jelenlegi helyzetkép, jövőbeni változások, fejlődési tendenciák és kihívások. In: Gaál Gyula - Hautzinger Zoltán (szerk.): Tanulmányok „A biztonság rendészettudományi dimenziói - változások és hatások” című tudományos konferenciáról. Pécs, 2012, 371-379. o. [Pécsi Határőr Tudományos Közlemények XIII.] 
Malét-Szabó Erika - Horváth Ferenc: Az új vezető-kiválasztási eljárás és a biztonság kapcsolata. In: Hegedús Judit (szerk.): Tanulmánykötet a belügyi vezető-kiválasztási eljárásról. Belügyminisztérium, Budapest, 2014, 13-19. o.

Malét-Szabó Erika: Az új belügyi vezető-kiválasztási rendszer elemeinek értékelése a szilárd erkölcsiség mutató mérésére javasolt SZEMmodell tükrében. In: Malét-Szabó Erika (szerk): Az erkölcsi értékrend és a személyiség közötti kapcsolat vizsgálati szempontjai. Belügyminisztérium, Budapest, 2015, 156-191. o.

Nagy Beáta: Nők a vezetésben: nehézségek és lehetőségek. Szociológiai Szemle, 1993/3-4., 147-166. o.

Nagy Beáta - Vicsek Lilla Mária: Mit ér a női vezető szava? Századvég, 2006/41.

Nguyen, Luu Lan Anh: A férfiak és nők a munka világában. Nemi szerepek a munkahelyen. Magyar Pszichológiai Szemle, 2005/1.

Sümegi Bernadett: Nők a vezetésben: nehézségek és lehetőségek. 2007. http//www.elib.kkf.hu Szabó Szilvia: Vezetői kompetenciaalapú képzés a rendvédelem (rendőrség, határőrség) állománya körében. Kard és Toll, 2006/3. 